\title{
Musculoskeletal Findings, Connective and Soft Tissue Findings Domain
}

National Cancer Institute

\section{Source}

National Cancer Institute. Musculoskeletal Findings, Connective and Soft Tissue Findings

Domain. NCl Thesaurus. Code C102674.

A subject domain utilized for the submission of information encompassing and representing data, vocabulary or records related to musculoskeletal findings, connective and soft tissue findings. 